residues/molecule of insulin of molecular weight 5734. The results may be slightly less accurate than would appear since Harfenist (1953) has reported that the complete release of valine from insulin is slow. She found the equivalent of $4 \cdot 73$ residues/ molecule after hydrolysis in 5.7 $\mathrm{N}$-hydrochloric acid in vacuo for $24 \mathrm{hr}$. at $110^{\circ}, 4.93$ residues $/$ molecule after $48 \mathrm{hr}$. and $5 \cdot 14$ residues/molecule after $96 \mathrm{hr}$. For isoleucine (to which the single resistant valine residue seems to be bound) the corresponding values were $0.66,0.80$ and 0.97 residue/molecule after 24 , 48 and $96 \mathrm{hr}$. respectively. Between 80 and $93 \%$ of the isoleucylvalyl grouping appears to break down in $48 \mathrm{hr}$., so the total valine content of the $45 \mathrm{hr}$. hydrolysate used here should have been equivalent to $4 \cdot 80-4 \cdot 93$ residues $/$ molecule. For the same batch of insulin, R. Nunnikhoven (personal communication), while working in the Laboratorium voor Physiologische Chemie, Amsterdam, found a valine content of $4 \cdot 7$ residues/molecule after a $22 \mathrm{hr}$. hydrolysis with $6 \mathrm{~N}$-hydrochloric acid in vacuo at $110^{\circ}$, which agrees well with Harfenist's (1953) values. The value determined by the dinitrophenylation method is probably $1-5 \%$ too high but it is still an accurate result.

The determination of valine by the method described is relatively simple and rapid. Though one must allow time for dinitrophenylation and extraction, many samples can be treated at a time. Several columns can also be run simultaneously, the number depending on the experience of the operator. DNP-valine emerges from the column in 30-40 min.; there is thus no bottle-neck, as often occurs in separation and analysis of amino acid mixtures by ion-exchange resins and reaction with ninhydrin. The extinction values of DNP-valine have been read at $410 \mathrm{~m} \mu$ as well as at $363 \mathrm{~m} \mu$ with almost as good results. A colorimeter can therefore be used in place of a spectrophotometer.

\section{SUMMARY}

1. A method is described for the quantitative determination of valine as its dinitrophenyl derivative. It is simple, accurate and requires no special apparatus. The range is $0 \cdot 1-1 \cdot 5 \mu$ moles of valine and several determinations may be done in parallel.

2. Recoveries of valine were good even when less than $1 \mu \mathrm{g}$. of valine was used so that the amounts present had to be determined in terms of radioactivity.

3. The valine content of a purified insulin sample, determined by this method, agreed closely with the calculated value.

\section{REFERENCES}

Hanes, C. S. (1961). Canad. J. Biochem. Physiol. 39, 119. Harfenist, E. J. (1953). J. Amer. chem. Soc. 75, 5528.

Krol, S. (1952). Biochem. J. 52, 227.

Levy, A. L. (1954). Nature, Lond., 174, 126.

Matheson, N. A. (1963). Biochem. J. 88, 146.

Moore, S., Spackman, D. H. \& Stein, W. H. (1958). Analyt. Chem. 30, 1185.

Moore, S. \& Stein, W. H. (1954). J. biol. Chem. 211, 893.

Ryle, A. P., Sanger, F., Smith, L. F. \& Kitai, R. (1955). Biochem. J. 60, 541.

Sanger, F. (1949). Biochem. J. 45, 563.

Schroeder, W. A. \& LeGette, J. (1953). J. Amer. chem. Soc. 75, 4612.

Synge, R. L. M. \& Youngson, M. A. (1961). Biorhem. J. 78, 708.

Tigane, E., Wade, E. H. M., Wong, J. T. \& Hanes, C. S. (1961). Canad. J. Biochem. Physiol. 39, 428.

Biochem. J. (1963) 88, 155

\title{
The Metabolism of Propionate in the Isolated Cow's Udder
}

\author{
By M. A. RAAFAT,* R. VERBEKE AND G. PEETERS \\ Physiological Department of the Veterinary College, University of Ghent, Belgium
}

(Received 1 February 1963)

Propionate is recognized as one of the principal products of carbohydrate fermentation by the micro-organisms inhabiting the rumen of cows (Elsden \& Phillipson, 1948). When $\left[1-{ }^{14} \mathrm{C}\right]$ propionate was added to the perfusion blood of the isolated cow's udder, an appreciable specific radio-

* Present address: Faculty of Agriculture, Cairo University, Giza, Egypt. activity was observed in the fatty acids containing an even number of $\mathrm{C}$ atoms/molecule but highest activity was found in the fatty acids containing an odd number of $\mathrm{C}$ atoms/molecule (James, Peeters \& Lauryssens, 1956). In the present paper further studies on the metabolism of propionate by the perfused cow's udder are reported. The incorporation of ${ }^{14} \mathrm{C}$ from $\left[1{ }^{14} \mathrm{C}\right]$ propionate into organic 
acids and glutamic acid was studied and compared with that of ${ }^{14} \mathrm{C}$ from $\left[1-{ }^{14} \mathrm{C}\right]$ hexanoate and $\left[3-{ }^{14} \mathrm{C}\right]$ butyrate.

\section{EXPERIMENTAL}

Perfusion experiments. The organic acids were isolated from ground cow-udder tissue that had been stored under ethanol at $-15^{\circ}$. The tissue was obtained from three isolated lactating-half-udder preparations that had been perfused several months before. Glutamic acid was isolated from milk casein obtained from the same perfusion experiments.

The isolated half-udder preparations were perfused with heparin-treated oxygenated cow's blood at $37^{\circ}$ under constant pressure (Peeters \& Massart, 1952). In the first experiment $1 \mathrm{mc}$ of $\left[1{ }^{14} \mathrm{C}\right]$ propionate was added to the perfusion blood (Verbeke, Aqvist \& Peeters, 1957). The second perfusion experiment was carried out with $0.5 \mathrm{mc}$ of $\left[3{ }^{14} \mathrm{C}\right]$ butyrate (Lauryssens, Verbeke, Peeters \& Reinards, 1960). In the third perfusion $1 \mathrm{mc}$ of $\left[1-{ }^{14} \mathrm{C}\right]$ hexanoate was added to the blood (Lauryssens, Verbeke, Peeters \& Donck, 1959). For more details about the perfusion experiments the reader is referred to these papers.

Isolation of Krebs cycle acids. Citric acid, succinic acid and malic acid were isolated by chromatography on Dowex 1 and silica-gel columns as described by Verbeke, Lauryssens, Peeters \& James (1959). Since only microgram quantities of malic acid were obtained in the column eluates, this acid was purified by paper chromatography (Kalbe, 1954). The acid solution was applied to the paper as a streak and the acid was localized after development with methyl red indicator solution at $\mathrm{pH}$ 8.0. After elution with water, malic acid was determined by the spot-area method (Block, Durrum \& Zweig, 1955a).

Isolation of keto acids. The keto acids $(\alpha$-oxoglutaric acid, pyruvic acid and glyoxylic acid) were isolated as 2,4dinitrophenylhydrazones from the deproteinized uddertissue extracts by repeated extractions with ether (Bassett $\&$ Harper, 1958). The combined ether layers were washed with acidified water. The 2,4-dinitrophenylhydrazones were purified from contaminating material by extraction with $10 \%(\mathrm{w} / \mathrm{v}) \mathrm{Na}_{2} \mathrm{CO}_{3}$. The alkaline aqueous layer was acidified with $\mathrm{HCl}$ and re-extracted with ether. The ether was evaporated and the 2,4-dinitrophenylhydrazones were dissolved in a minimal volume of ethyl acetate. The resulting solution was applied as a streak to the paper and the 2,4-dinitrophenylhydrazones were separated by descending chromatography with butan-1-ol-ethanol-0.5 $\mathrm{N}$-ammonia (7:1:2, by vol.) (El Hawary \& Thompson, 1953) and 2methylbutan-2-ol-ethanol-water $(5: 1: 4$, by vol.) (Altmann, Crook \& Datta, 1951) as solvents. Distinct bands of pyruvic 2,4-dinitrophenylhydrazone, $\alpha$-oxoglutaric 2,4dinitrophenylhydrazone and glyoxylic 2,4-dinitrophenylhydrazone were obtained. The strips containing the 2,4dinitrophenylhydrazones were eluted with water at $0^{\circ}$. The aqueous solution of the 2,4-dinitrophenylhydrazones (approx. $5 \mathrm{ml}$.) was acidified with dilute $\mathrm{HCl}$ to $\mathrm{pH} \mathrm{3-5.}$ Palladium-charcoal $(5 \mathrm{mg}$.) was added as catalyst. The hydrogenation of the 2,4-dinitrophenylhydrazones to the corresponding amino acids was carried out at normal pressure by passing a constant stream of $\mathrm{H}_{2}$ through the solution for $12 \mathrm{hr}$. at room temperature. The amino acid solutions were desalted (Drèze, Moore \& Bigwood, 1954) and the amino acids purified by paper chromatography with different solvents: ethyl methyl ketone-propionic acid-water (25:5:6, by vol.) (Himes \& Metcalfe, 1959); phenol-water (5:1, v/v) (Block, Durrum \& Zweig, 1955b) and butan-1-ol-acetic acid-water $(4: 1: 5$, by vol.) (Block et $a l .1955 b$ ). The amino acids were localized on a strip by reaction with ninhydrin. After elution with water, the amino acid concentration in the eluate was determined by quantitative ninhydrin reaction on a portion of the solution (Cocking \& Yemm, 1954).

Degradation of succinic acid. Before degradation, succinic acid was diluted 40 -fold with carrier and purified by vacuum sublimation at $120^{\circ}$ (Edson, Hunter, Kulka \& Wright, 1959). The anhydride of succinic acid was degraded with azide as described by Phares \& Long (1955).

Degradation of glutamic acid. Glutamic acid from the [1. $\left.{ }^{14} \mathrm{C}\right]$ propionate experiment was treated with chloramineT, yielding succinic semialdehyde (Mosbach, Phares \& Carson, 1951). This aldehyde was crystallized as the 2,4dinitrophenylhydrazone. The derivative was oxidized to $\mathrm{CO}_{2}$ in the Van Slyke-Folch oxidation mixture (Sakami, 1955c). This enabled us to calculate the specific radioactivity of C-2-C-5 of glutamic acid. That of C-1 of glutamic acid was obtained by ninhydrin reaction on glutamic acid.

Glutamic acid from the $\left[1-{ }^{14} \mathrm{C}\right]$ hexanoate experiment was degraded as described by Mosbach et al. (1951), with the modifications of Koeppe \& Hill (1955). The propylamine, obtained by the reaction of $\mathrm{NaN}_{3}$ on butyric acid, was oxidized to $\mathrm{CO}_{2}$ with $\mathrm{AgNO}_{3}$-persulphate mixture [1 g. of $\mathrm{K}_{2} \mathrm{~S}_{2} \mathrm{O}_{8}$ plus $2 \mathrm{ml}$. of $5 \%$ (w/v) $\mathrm{AgNO}_{3}$ solution] (Sakami, $1955 b$ ), giving C-2-C-4 of glutamic acid.

In all degradation experiments a portion of the compound investigated was oxidized to $\mathrm{CO}_{2}$ (Sakami, 1955a) as a check on the procedures.

Radioactivity measurements. All radioactivity measurements were made with a windowless flow counter.

Samples of organic acids and amino acids were plated on plastic disks and assayed for ${ }^{14} \mathrm{C}$. The count rates obtained and the thicknesses of materials used are of the same order as those described by Verbeke et al. (1959). Under the experimental conditions used, $1 \mu \mathrm{mc}$ at infinite thinness corresponds to 660 counts/min. in our counting system (Verbeke et al. 1959). In Table 1 the radioactivities $(\mu \mathrm{mc})$ are recorded as means \pm S.E.M. from at least triplicate samples.

The ${ }^{14} \mathrm{CO}_{2}$ liberated in degradation experiments was converted into $\mathrm{Ba}^{14} \mathrm{CO}_{3}$ for counting. The $\mathrm{Ba}^{14} \mathrm{CO}_{3}$ samples were mounted directly on removable glass-filter disks of area $3.2 \mathrm{~cm} .{ }^{2}$ (Pinajian \& Cross, 1951) (wt. about $20 \mathrm{mg}$./ $\mathrm{cm}^{2}$, equivalent to infinite thickness for counting). The count rates obtained were corrected for the dead-time of the instrument $(100 \mu \mathrm{sec}$.$) and background. Sufficient$ counts were taken to give s.e. not more than $\pm 2 \%$.

\section{RESULTS}

Organic acids. The Krebs-cycle acids isolated from the udder-tissue extracts after perfusion with $\left[1 .{ }^{14} \mathrm{C}\right]$ propionate had a very high specific radioactivity (Table 1). The incorporation of ${ }^{14} \mathrm{C}$ into pyruvic acid was rather small compared with the specific radioactivities found in citric acid, succinic acid, malic acid and $\alpha$-oxoglutaric acid. A very low specific radioactivity was found in 
glyoxylic acid. The picture of the relative specific radioactivities in the organic acids isolated after perfusion with $\left[1-{ }^{14} \mathrm{C}\right]$ propionate is similar to the one obtained after perfusion with $\left[1-{ }^{14} \mathrm{C}\right]$ hexanoic acid.

Degradation of succinic acid and glutamic acid. The results of the degradations are shown in Table 2.

Almost all of the ${ }^{14} \mathrm{C}$ of succinic acid isolated in the $\left[1-{ }^{14} \mathrm{C}\right]$ propionate experiment was recovered from the carboxyl group, only $1 \%$ of the total being found in the methylene group. Similar results were obtained by the degradation of succinic acid isolated in the $\left[3-{ }^{14} \mathrm{C}\right]$ butyrate experiment.

In glutamic acid isolated from the $\left[1-{ }^{14} \mathrm{C}\right]$ propionate experiment, almost all of the ${ }^{14} \mathrm{C}$ was localized in the $\alpha$-carboxyl group, only $3.8 \%$ being measured in C-3-C-5. This is in sharp contrast with the results obtained by degradation of

Table 1. Specific radioactivities of organic acids isolated from udder tissues after perfusion with $\left[1-{ }^{14} \mathrm{C}\right]$ propionate or $\left[1{ }^{14} \mathrm{C}\right]$ hexanoate

Experimental details are given in the text. Specific radioactivities ( $\mu \mathrm{mc} / \mathrm{mg}$. of $\mathrm{C}$ ) are given as means \pm S.E.M. N.D., Not determined.

Organic acid

Citric acid

Succinic acid

Malic acid

$\alpha$-Oxoglutaric acid

Pyruvic acid

Glyoxylic acid

$$
\left[1{ }^{14} \mathrm{C}\right] \text { Propionate }
$$
expt.

$16 \cdot 4 \pm 0 \cdot 2$
$14 \cdot 6 \pm 0 \cdot 3$
$21 \cdot 1 \pm 1 \cdot 3$
$19 \cdot 2 \pm 0 \cdot 4$
$1 \cdot 28 \pm 0 \cdot 09$
$0 \cdot 43 \pm 0 \cdot 04$

$\left[1-{ }^{14} \mathrm{C}\right]$ Hexanoate expt.

$15 \cdot 1 \pm 0 \cdot 4$

$33 \cdot 7 \pm 1 \cdot 3$

N.D.

$38 \cdot 0 \pm 0 \cdot 8$

$3 \cdot 05 \pm 0 \cdot 12$

$0 \cdot 36 \pm 0 \cdot 09$ glutamic acid from the experiment with $\left[1 .{ }^{14} \mathrm{C}\right]$ hexanoic acid: here only $31 \cdot 3 \%$ of the ${ }^{14} \mathrm{C}$ was detected in the $\alpha$-carboxyl group but $66.5 \%$ was recovered in the $\gamma$-carboxyl group (C-5).

The recovery of ${ }^{14} \mathrm{C}$ in the degradations was satisfactory and within the limits of error of the methods used.

\section{DISCUSSION}

The results obtained in the $\left[1^{14} \mathrm{C}\right]$ hexanoate and $\left[3-{ }^{14} \mathrm{C}\right]$ butyrate experiments are consistent with the oxidation of these substrates via acetyl units and the Krebs cycle. These acetyl components are labelled in the carboxyl group and give rise to the formation of ${ }^{14} \mathrm{C}$-labelled citric acid, ${ }^{14} \mathrm{C}$-labelled $\alpha$-oxoglutaric acid and ${ }^{14} \mathrm{C}$-labelled succinic acid. Succinic acid will be labelled in the carboxyl group. The $\alpha$ - and $\gamma$-carboxyl groups of $\alpha$-oxoglutaric acid will contain respectively one-third and two-thirds of the total ${ }^{14} \mathrm{C}$ of the molecule. A similar ${ }^{14} \mathrm{C}$ distribution may be expected in the corresponding carboxyl groups of glutamic acid, which is derived from $\alpha$-oxoglutaric acid by transamination. Our results obtained after the degradation of glutamic acid from the $[1-14 \mathrm{C}]$ hexanoate experiment are in keeping with these expectations.

Different pathways of propionate metabolism are known to occur in animal tissues:

(1) The succinate path. Experiments on the distribution of ${ }^{14} \mathrm{C}$ from labelled propionate in tissue glycogen (Lorber, Lifson, Sakami \& Wood, 1950), in acetyl groups (Shreeve, 1952) or in lactate (Daus, Meinke \& Calvin, 1952) indicated the occurrence of a symmetrical intermediate between propionate and pyruvate such as would be formed

Table 2. Distribution of ${ }^{14} \mathrm{C}$ in succinic acid and glutamic acid after perfusion of cow's udder uith ${ }^{14} \mathrm{C}$-labelled substrates

Experimental details are given in the text.

\begin{tabular}{|c|c|c|c|c|}
\hline Experiment & $\begin{array}{c}\text { Sources of } \mathrm{Ba}^{14} \mathrm{CO}_{3} \\
\text { assayed }\end{array}$ & $\begin{array}{c}\text { Sp. radio- } \\
\text { activity } \\
\text { (counts/min. } \\
\text { at infinite } \\
\text { thickness) }\end{array}$ & $\begin{array}{l}\text { Percentage } \\
\text { distribution } \\
\text { of }{ }^{14} \mathrm{C}\end{array}$ & $\begin{array}{c}\text { Recovery } \\
\text { of }{ }^{14} \mathrm{C}^{*}\end{array}$ \\
\hline$\left[1-{ }^{14} \mathrm{C}\right]$ Propionate & $\begin{array}{l}\text { Succinic acid } \\
\text { Carboxyl C (C-1, C-4) } \\
\text { Methylene C (C-2, C-3) }\end{array}$ & $\begin{array}{r}5505 \\
11266 \\
118\end{array}$ & $\begin{array}{r}-\overline{99 \cdot 0} \\
1 \cdot 0\end{array}$ & $\begin{array}{c}103 \cdot 4 \\
-\end{array}$ \\
\hline$\left[3^{-14} \mathrm{C}\right]$ Butyrate & $\begin{array}{l}\text { Succinic acid } \\
\text { Carboxyl C (C-1, C-4) } \\
\text { Methylene C (C-2, C-3) }\end{array}$ & $\begin{array}{r}10817 \\
21275 \\
146\end{array}$ & $\begin{array}{r}-\overline{99 \cdot 3} \\
0 \cdot 7\end{array}$ & $\begin{array}{c}99 \cdot 0 \\
-\end{array}$ \\
\hline$\left[1{ }^{14} \mathrm{C}\right]$ Propionate & $\begin{array}{l}\text { Glutamic acid } \\
\alpha \text {-Carboxyl (C-1) } \\
\text { C-2-C-5 }\end{array}$ & $\begin{array}{r}2248 \\
10960 \\
108\end{array}$ & $\begin{array}{r}\overline{96 \cdot 2} \\
3 \cdot 8\end{array}$ & $\begin{array}{c}101 \cdot 3 \\
-\end{array}$ \\
\hline$\left[1{ }^{14} \mathrm{C}\right]$ Hexanoate & $\begin{array}{l}\text { Glutamic acid } \\
\alpha \text {-Carboxyl C (C-1) } \\
\text { C-2-C-4 } \\
\gamma \text {-Carboxyl C (C-5) }\end{array}$ & $\begin{array}{r}3830 \\
5970 \\
142 \\
12675\end{array}$ & $\begin{array}{r}-\overline{31 \cdot 3} \\
2 \cdot 2 \\
66 \cdot 5\end{array}$ & $\begin{array}{c}99 \cdot 6 \\
- \\
-\end{array}$ \\
\hline
\end{tabular}

* Specific radioactivity of total molecule $\times$ no. of $\mathrm{C}$ atoms $=100$. 
if propionate were first carboxylated to succinate followed by the oxidation of the dicarboxylic acid through the Krebs cycle. Evidence was accumulated at the enzyme level that the principal pathway of propionate oxidation by mammalian tissues involves activation of propionate and carboxylation of propionyl-CoA to give methylmalonyl-CoA (Lardy \& Peanasky, 1953; Lardy \& Adler, 1956; Friedberg, Adler \& Lardy, 1956; Flavin, Ortiz \& Ochoa, 1955; Flavin, Castro-Mendoza \& Beck, $1956 a$; Flavin, Castro-Mendoza \& Ochoa, 1956b; Katz \& Chaikoff, 1955). Finally methylmalonyl$\mathrm{CoA}$ isomerizes to form succinyl-CoA (Flavin et al. $1956 a$; Beck \& Ochoa, 1958).

(2) The malonic semialdehyde path was suggested by Rendina \& Coon (1957). Propionyl-CoA would thus pass through the following intermediates: acrylyl-CoA, $\beta$-hydroxypropionyl-CoA, free $\beta$-hydroxypropionate and malonic semialdehyde. In animal tissue, malonic semialdehyde was shown to be aminated to $\beta$-alanine. In plant tissue, Giovanelli \& Stumpf (1958) found malonic semialdehyde to be oxidized to acetyl-CoA and $\mathrm{CO}_{2}$, C-3 of propionate becoming C-1 of acetate.

(3) In a system purified from Clostridium kluyveri, Vagelos (1960) has shown that $\beta$-hydroxypropionyl-CoA is oxidized, in succession, to malonyl semialdehyde-CoA and malonyl-CoA. The latter would yield an acetyl unit from C-1 and C-2. This pathway could explain the synthesis of fatty acids with an even number of $\mathrm{C}$ atoms/molecule from $\left[1-{ }^{14} \mathrm{C}\right]$ propionate.

(4) Direct oxidation of propionate by animal tissues was postulated through acrylate and lactate to pyruvate (Mahler \& Huennekens, 1953).

Our present results together with previous results are not consistent with the major operation of the malonic semialdehyde or malonate pathways in the cow's udder. If the oxidation of $\left[1 .{ }^{14} \mathrm{C}\right]$ propionate proceeded solely via the malonic. semialdehyde pathway little or no radioactivity would be detected in the acids of the Krebs cycle. With the malonate pathway the yield of labelled acetyl units from $\left[1-{ }^{14} \mathrm{C}\right]$ propionate would be expected to be large. James et al. (1956) observed some formation of labelled fatty acids with an even number of $\mathrm{C}$ atoms/molecule from $\left[{ }^{1 .{ }^{14}} \mathrm{C}\right]$ propionate. However, if $\left[1{ }^{14} \mathrm{C}\right]$ propionate yielded primarily $\left[1-{ }^{14} \mathrm{C}\right]$ acetyl groups by the malonate pathway, the distribution of ${ }^{14} \mathrm{C}$ should be similar in glutamate from $\left[1-{ }^{14} \mathrm{C}\right]$ propionate and $\left[1{ }^{14} \mathrm{C}\right]$ hexanoate, but they were in fact different. The high radioactivity in the $\gamma$-carboxyl group of glutamate, as observed with $\left[1-{ }^{14} \mathrm{C}\right]$ hexanoate, is to be expected if the ${ }^{14} \mathrm{C}$ enters the Krebs cycle mainly by acetyl-CoA.

Our results are consistent with the oxidation of propionate via the succinate path. According to that pathway the ${ }^{14} \mathrm{C}$ of $\left[1{ }^{14} \mathrm{C}\right]$ propionate will be incorporated to a high extent into the acids of the Krebs cycle, and succinic acid will be labelled in the carboxyl group. Glutamic acid, which is derived from $\alpha$-oxoglutaric acid, will be labelled in the $\alpha$-carboxyl group only. The transfer of ${ }^{14} \mathrm{C}$ to pyruvic acid will be less extensive. In both the $\left[1{ }^{14} \mathrm{C}\right]$ propionate and the $\left[{ }^{14} \mathrm{C}\right]$ hexanoate experiments the formation of labelled pyruvate is postulated to proceed primarily via oxaloacetate as an intermediate.

Katz \& Kornblatt (1962) have studied the oxidation and the incorporation of $\left[{ }^{14} \mathrm{C}\right]$ propionate in fatty acids and water-soluble products in slices prepared from the mammary glands of lactating rats. Their results are consistent with propionate metabolism proceeding by the succinate pathway. A similar conclusion was reached by Black \& Kleiber (1962) in experiments on lactating cows. $\left[2-{ }^{14} \mathrm{C}\right]$ Propionate or $\left[2-{ }^{14} \mathrm{C}\right]$ acetate were injected into the cistern of one quarter-udder or into the jugular vein. The ${ }^{14} \mathrm{C}$ distributions in the glutamic acid and serine of casein are best explained if propionate is metabolized by way of succinate.

The possibility that $\left[1^{-14} \mathrm{C}\right]$ propionate is directly oxidized to pyruvate and enters the Krebs cycle via pyruvate has to be considered. Fixation of $\mathrm{CO}_{2}$ by pyruvate followed by randomization of carbon in the 'dicarboxylic acid shuttle' would explain the labelling of the acids of the Krebs cycle and the distributions of ${ }^{14} \mathrm{C}$ in succinic acid and glutamic acid as well. However, the low specific radioactivity of pyruvate as compared with that of the acids of the Krebs cycle is not consistent with the pyruvate pathway. Verbeke et al. (1957) observed that the specific radioactivities of aspartic acid and glutamic acid of milk casein were much higher than that of alanine in perfusion experiments carried out with $\left[1-{ }^{14} \mathrm{C}\right]$ propionate. These findings are in keeping with our present results.

The specific radioactivity of glyoxylic acid was very low in the $\left[1-{ }^{14} \mathrm{C}\right]$ hexanoate and $\left[1-{ }^{14} \mathrm{C}\right]$ propionate experiments, and does not provide evidence for the presence of reactions of the glyoxylate cycle in the cow's udder. The search for the specific enzymes of this cycle in animals has so far been without success (Madsen, 1958).

\section{SUMMARY}

1. Excised cows' udders were perfused with blood containing $\left[1^{-14} \mathrm{C}\right]$ propionate, $\left[1-{ }^{14} \mathrm{C}\right]$ hexanoate or $\left[3-^{14} \mathrm{C}\right]$ butyrate.

2 . In the $\left[1-{ }^{14} \mathrm{C}\right]$ propionate and $\left[1-{ }^{14} \mathrm{C}\right] \mathrm{hex}$ anoate experiments, several acids of the Krebs cycle, pyruvate and glyoxylate were isolated from the tissue. Glutamic acid was isolated from milk casein. In the $\left[1-{ }^{14} \mathrm{C}\right]$ butyrate experiment, succinic acid alone was isolated. The distributions of ${ }^{14} \mathrm{C}$ in 
succinic acid and glutamic acid were determined by degradation.

3. The ${ }^{14} \mathrm{C}$ from $\left[{ }^{1-14} \mathrm{C}\right]$ propionate and $[1-14 \mathrm{C}]$ hexanoate was incorporated to a large extent into the acids of the Krebs cycle and to a smaller extent into pyruvic acid. The radioactivity of glyoxylic acid was very low in both cases. The ${ }^{14} \mathrm{C}$ activity of succinic acid from the $\left[1{ }^{14} \mathrm{C}\right]$ propionate and [1-14C]butyrate experiments was localized in the carboxyl groups. The ${ }^{14} \mathrm{C}$ distribution in glutamic acid from the $\left[1-{ }^{14} \mathrm{C}\right]$ hexanoate experiment was different from that in glutamic acid from the $[1-14 \mathrm{C}]$ propionate experiment.

4. Our results are consistent with propionate metabolism proceeding by the succinate pathway and there is no evidence for an alternate major pathway.

This work was supported by a grant of the Belgian I.R.S.I.A. Foundation and was carried out while M. A. Raafat was the holder of un International Atomic Energy Agency Fellowship, which he acknowledges with thanks.

\section{REFERENCES}

Altmann, S. M., Crook, E. M. \& Datta, S. P. (1951). Biochem. J. 49, lxiii.

Bassett, E. W. \& Harper, W. J. (1958). J. Dairy Sci. 41, 1206.

Beck, W. S. \& Ochoa, S. (1958). J. biol. Chem. 232, 931.

Black, A. L. \& Kleiber, M. (1962). In Use of Radioisotopes in Animal Biology and the Medical Sciences, vol. 2, p. 137. London and New York: Academic Press.

Block, R. J., Durrum, E. L. \& Zweig, G. (1955a). A Manual of Paper Chromatography and Paper Electrophoresis, p. 56. New York: Academic Press Inc.

Block, R. J., Durrum, E. L. \& Zweig, G. (1955b). A Manual of Paper Chromatography and Paper Electrophoresis, p. 111. New York: Academic Press Inc.

Cocking, E. C. \& Yemm, E. W. (1954). Biochem. J. 58, xii.

Daus, L., Meinke, M. \& Calvin, M. (1952). J. biol. Chem. 196, 77.

Drèze, A., Moore, S. \& Bigwood, E. J. (1954). Analyt. chim. Acta, $11,554$.

Edson, N. L., Hunter, G. J. E., Kulka, R. G. \& Wright, D. E. (1959). Biochem. J. 72, 249.

El Hawary, M. F.S. \& Thompson, R. H. S. (1953). Biochem. J. 53, 340.

Elsden, S. R. \& Phillipson, A. T. (1948). Annu. Rev. Biochem. 17, 705.
Flavin, M., Castro-Mendoza, H. \& Beck, W. S. (1956a). Fed. Proc. 15, 252.

Flavin, M., Castro-Mendoza, H. \& Ochoa, S. (1956b). Biochim. biophys. Acta, 20, 591.

Flavin, M., Ortiz, P. J. \& Ochoa, S. (1955). Nature, Lond., 176, 823.

Friedberg, F., Adler, J. \& Lardy, H. A. (1956). J. biol. Chem. 219, 943.

Giovanelli, J. \& Stumpf, P. K. (1958). J. biol. Chem. 231, 411.

Himes, J. B. \& Metcalfe, L. D. (1959). Analyt. Chem. 31, 1192.

James, A. T., Peeters, G. \& Lauryssens, M. (1956). Biochem. J. 64, 726.

Kalbe, H. (1954). Hoppe-Seyl. Z. 297, 19.

Katz, J. \& Chaikoff, I. L. (1955). J. Amer. chem. Soc. 77, 2659.

Katz, J. \& Kornblatt, J. (1962). J. biol. Chem. 237, 2466.

Koeppe, R. E. \& Hill, R. J. (1955). J. biol. Chem. 216, 813.

Lardy, H. A. \& Adler, J. (1956). J. biol. Chem. 219, 933.

Lardy, H. A. \& Peanasky, R. J. (1953). Physiol. Rev. 33, 560.

Lauryssens, M., Verbeke, R., Peeters, G. \& Donck, A. (1959). Biochem. J. 73, 71.

Lauryssens, M., Verbeke, R., Peeters, G. \& Reinards, M. (1960). J. Dairy Res. 27, 151.

Lorber, V., Lifson, N., Sakami, W. \& Wood, H. G. (1950). J. biol. Chem. 183, 531.

Madsen, N. B. (1958). Biochim. biophys. Acta, 27, 199.

Mahler, H. R. \& Huennekens, F. M. (1953). Biochim. biophys. Acta, 11, 575.

Mosbach, E. H., Phares, E. F. \& Carson, S. F. (1951). Arch. Biochem. Biophys. 33, 179.

Peeters, G. \& Massart, L. (1952). Arch. int. Pharmacodyn. 91, 388.

Phares, E. F. \& Long M. V. (1955). J. Amer. chem. Soc. 77, 2556.

Pinajian J. J. \& Cross, J. M. (1951). Analyt. Chem. 23, 1056.

Rendina, G. \& Coon, M. (1957). J. biol. Chem. 225, 523.

Sakami, W. (1955a). In Handbook of Isotope Tracer Methods, p. 1. Ed. by Sakami, W. Cleveland, Ohio: Western Reserve University.

Sakami, W. (1955b). In Handbook of Isotope Tracer Methods, p. 5. Ed. by Sakami, W. Cleveland, Ohio: Western Reserve University.

Sakami, W. (1955c). In Handbook of Isotope Tracer Methods, p. 125. Ed. by Sakami, W. Cleveland, Ohio: Western Reserve University.

Shreeve, W. W. (1952). J. biol. Chem. 195, 1.

Vagelos, P. R. (1960). J. biol. Chem. 235, 346.

Verbeke, R., Aqvist, S. \& Peeters, G. (1957). Arch. int. Physiol. Biochim. 65, 433.

Verbeke, R., Lauryssens, M., Peeters, G. \& James, A. T. (1959). Biochem. J. 73, 24. 